\title{
EFEKTIVITAS PEMBELAJARAN JARAK JAUH PADA MASA PANDEMI COVID-19
}

\author{
Zainal Abidin ${ }^{1}$, Adeng Hudaya ${ }^{2(*)}$, Dinda Anjani ${ }^{3}$ \\ Universitas Indraprasta PGRI Jakarta, Indonesia \\ julis.abidin@gmail.com ${ }^{1}$, adenghudaya.unindra@gmail.com ${ }^{2}$,dindaanjani@gmail.com ${ }^{3}$
}

\begin{abstract}
Received: 10 September 2020 Tujuan yang ingin dicapai penelitian ini adalah untuk mengetahui Revised: 06 Oktober 2020 efektivitas pembelajaran jarak jauh di masa pandemi covid-19 pada santri Accepted: 14 Oktober 2020 Rumah Al Qashwa tingkat SMP dan SMA di Poltangan Pejaten Timur. Metode yang digunakan dalam penelitian ini adalah metode kualitatif yang sifatnya deskriptif yang artinya penelitian yang mengacu pada teknik pengumpulan data yang dilakukan dengan wawancara mendalam dengan key informan dan informan. Adapun jumlah informan yang diambil dalam penelitian ini adalah sebanyak 15 Santri. Cara untuk memperoleh data dalam penelitian ini meliputi observasi, wawancara dan dokumentasi. Adapun teknik analisis data yang dipergunakan dalam penelitian ini adalah meliputi: pengumpulan data, penyajian data, reduksi data, triangulasi data, pengecekan anggota dan verifikasi data / kesimpulan. Berdasarkan hasil penelitian temuan dilapangan dapat disimpulkan bahwa proses pembelajaran yang dilakukan saat ini cukup efektif meskipun disana-sini masih ada beberapa hambatan yang mengganggu pembelajaran jarak jauh seperti masalah interaksi sosial guru dengan siswa dan ekonomi peserta didik yang nyaris belum siap.
\end{abstract}

Keywords: Covid-19, Efektivitas; Pembelajaran; Jarak Jauh

(*) Corresponding Author: Hudaya, adenghudaya.unindra@gmail.com, 085717804245

How to Cite: Abidin, Z., Hudaya, A., \& Anjani, D. (2020). Efektivitas Pembelajaran Jarak Jauh Pada Masa Pandemi Covid-19. Research and Development Journal of Education, 1(1), 131-146.

\section{INTRODUCTION}

Pandemi COVID-19 merupakan krisis kesehatan yang pertama dan terutama di dunia. Hal ini berimbas pada penutupan sekolah, perguruan tinggi dan universitas dibeberapa negara. Perserikatan Bangsa-Bangsa (PBB) menjadi gusar dengan adanya fakta tersebut. Organisasi Internasional yang bermarkas di New York, AS, itu menangkap bahwa salah satu sector yang terdampak oleh pandemi virus corona adalah sector pendidikan. Parahnya lagi, hal itu terjadi dalam tempo yang cepat dan skala yang luas. Berdasarkan laporan ABC News 7 Maret 2020, puluhan negara menutup sekolah dikarenakan wabah covid 19. Menurut data Organisasi Pendidikan, Keilmuan, dan Kebudayaan PBB (UNESCO), setidaknya terdapat 290,5 juta siswa di seluruh dunia yang aktivitas belajarnya menjadi terganggu akibat sekolah yang ditutup (Purwanto, dkk., 2020).

Dampak virus corona padamulanya sangat berpengaruh pada sektor perekonomian, tetapi juga saat ini dirasakan oleh dunia pendidikan. Kebijakan yang diambil oleh negara yang terdampak virus corona termasuk Indonesia harus meliburkan sekolah untuk sementara. Dibeberapa lembaga pendidikan mengharuskan mencari alternatif dalam proses pembelajaran. Sepertihalnya yang terjadi di Indonesia mulai dari jenjang sekolah dasar sampai perguruan tinggi atau universitas mengambil alternatif pembelajaran jarak jauh secara online. 
Menurut kompas, 28/03/2020 dampak virus COVID-19 terjadi diberbagai bidang seperti sosial, ekonomi, pariwisata dan pendidikan. Surat Edaran (SE) yang dikeluarkan pemerintah pada 18 Maret 2020 menyatakan bahwa untuk mengurangi penyebaran virus corona, maka segala kegiatan yang dilakukan baik di dalam maupun luar ruangan pada semua sektor untuk sementara waktu ditunda pelaksanaannya. Pada tanggal 24 maret 2020 Menteri Pendidikan dan Kebudayaan Republik Indonesia mengeluarkan Surat Edaran Nomor 4 Tahun 2020 Tentang Pelaksanaan Kebijakan Pendidikan Dalam Masa Darurat Penyebaran COVID-19, dalam Surat Edaran tersebut dijelaskan bahwa proses belajar dilaksanakan di rumah melalui pembelajaran daring/jarak jauh untuk memberikan pengalaman kepada siswa, pemebalajaran di arahkan kepda pemahaman tentang penyebaran dan pencegahan wabah virus corona.

Korban akibat wabah covid-19, tidak hanya pada jenjang sekolah dasar, mengah dan jenjang tingkat atas, melainkan berdampak juga pada perguruan tinggi atau tingkat universitas. Seluruh jenjang pendidikan yang berada dibawah kemendikbud RI dan di bawah Kemenag RI semuanya mengalami dampak negative akibat virus corona, sehingga mereka "dipaksa" untuk mengikuti pemebelajaran jarak jauh (di rumah) dalam rangka mencegah penulran covid-19. Padahal tidak semua pelajar, siswa dan mahasiswa terbiasa belajar melalui Online.

Kemampuan dalam pembelajaran secara online masih banyak siswa, guru dan dosen belum mahir terutama bagi siswa, guru ataupun dosen yang berada di daerahdaerah pedalam. Pembelajaran daring merupakan pemanfaatan jaringan internet dalam proses pembelajaran. Dengan pembelajaran jarak jauh/ daring baik siswa, guru maupun dosen memiliki keleluasaan waktu dalam pelaksanaannya. Adapun platform yang dapat digunakan dalam pembelajaran jarak jauh ini antara lain: google classroom, goggle meet, zoom, Wa grup dan lain-lain.

Gikas \& Grant (Firman \& Rahman, 2020) menyatakan "Pembelajaran online pada pelaksanaannya membutuhkan dukungan perangkat-perangkat mobile seperti telepon pintar, tablet dan laptop yang dapat digunakan untuk mengakses informasi dimana saja dan kapan saja." Korucu \& Alkan (Firman \& Rahman, 2020) menyatakan "Penggunaan teknologi mobile memiliki kontribusi besar di dunia pendidikan, termasuk di dalamnya adalah pencapaian tujuan pembelajaran jarak jauh. Berdasarkan permasalahan di atas, maka dalam penelitian ini akan dibahas tentang efektivitas pembelajaran jarak jauh di masa pandemi covid 19.

\section{LITERATURE REVIEW}

\section{Covid-19}

\section{Pengertian Covid-19}

Virus Corona Atau severe acute respiratory syndrome coronavirus (SARS$\mathrm{CoV}-2$ ) adalah virus yang menyerang sistem pernapasan yang menyebabkan gangguan pada sistem pernapasan, pneumonia akut, sampai kematian. Yurianto dan Bambang Wibowo (2020) (Dewi, 2020:56) menyatakan : Corona virus itu sendiri adalah keluarga besar virus yang menyebabkan penyakit mulai dari gejala ringan sampai berat.Ada setidaknya dua jenis corona virus yang diketahui menyebabkan penyakit yang dapat menimbulkan gejala berat.Coronavirus Diseases 2019 (COVID-19) adalah penyakit jenis baru yang belum pernah diidentifikasi sebelumnya pada manusia. Tanda dan gejala umum infeksi COVID-19 antara lain gejala gangguan pernapasan akut seperti demam, batuk, dan sesak napas. Masa inkubasi rata-rata 5-6 hari dengan masa inkubasi terpanjang 14 hari. 
Menurut Kementerian Kesehatan Indonesia (Usman \& Aswar, 2020:142) Virus corona atau covid-19 adalah merupakan bagian keluarga besar virus corona yang menyebabkan penyakit pada manusia dan hewan, pada manusia biasanya menyebabkan penyakit infeksi saluran pernafasan, mulai flu biasa hingga penyakit yang serius seperti Middle East Respiratory Syndrome (MERS) dan sindrom pernafasan akut berat/Severe Acute Respiratory Syndrome (SARS), coronavirus jenis baru yang ditemukan pada manusia sejak kejadian luar biasa muncul di Wuhan China, dan menyebabkan penyakit Coronavirus Disease-2019 (COVID-19).

Dapat disimpulkan diatas bahwa covid-19 adalah Coronavirus jenis baru yang ditemukan pada manusia sejak kejadian luar biasa muncul di Wuhan China, dan menyebabkan penyakit Coronavirus Disease-2019 (COVID-19). Virus baru yang menyebabkan penyakit pada manusia mulai dari gejala ringan sampai berat dan menyerang gangguan pada sistem pernapasan seperti demam, batuk, dan sesak napas, pneumonia akut, sampai kematian. Masa inkubasi rata-rata 5-6 hari dengan masa inkubasi terpanjang 14 hari.

\section{Gejala Infeksi Virus Covid-19}

Menurut Center for Disease Control USA (Tandra, 2020:11) Kriteria klinis infeksi covid-19 adalah sebagai berikut:

a. Demam atau tanda infeksi saluran napas bagian bawah disertai riwayat pernah kontak dengan pasien covid-19 (yang dikonfirmasi dengan laboratorium) dalam 14 hari terakhir.

b. Demam atau tanda infeksi saluran napas bagian bawah disertai riwayat baru datang dari provinsi Hubei, Cina, dalam 14 hari terakhir.

c. Demam atau tanda infeksi saluran napas bagian bawah hingga perlu rawat inap di rumah sakit disertai riwayat datang dari daratan Cina dalam 14 hari terakhir.

\section{Langkah-langkah Umum Pencegahan Infeksi Pernapasan Virus}

Menurut (Tandra, 2020:25) langkah-langkah umum untuk pencegahan infeksi pernapasan virus meliputi:

a. Cuci tangan dengan sabun dan air,

b. Hindari menyentuh mata, hidung, dan mulut dengan tangan.

c. Jauhi kontak dengan orang yang sakit.

d. Orang sakit harus tinggal istirahat di rumah.

e. Batuk dan bersin harus ditutup dengan tisu

f. Benda dan permukaan yang sering disentuh harus dibersihkan dan di desinfeksi secara teratur.

\section{Prosedur Pencegahan dan Pengendalian Infeksi untuk Isolasi di Rumah}

Prosedur pencegahan dan pengendalian infeksi untuk isolasi di rumah yang dianjurkan oleh Pedoman Kesiapsiagaan Menghadapi Covis-19 Revisi ke-4 27 Maret 2020, oleh Direktoral Jendral Pencegahan dan Pengendalian Penyakit Depkes RI (Tandra, 2020:26), adalah sebagai berikut:

a. Tempatkan pasien atau orang dalam ruangan tersendiri yang memiliki ventilasi yang baik.

b. Batasi pergerakan dan minimalkan berbagi ruangan yang sama.

c. Anggota keluarga yang lain sebaiknya tidur di kamar yang berbeda,

d. Batasi jumlah orang yang merawat pasien.

e. Lakukan hand hygiene (cuci tangan) segera setiap kontak dengan pasien atau lingkungan pasien. 
f. Jika mencuci tangan menggunakan air dan sabun, handuk kertas sekali pakai direkomendasikan.

g. Untuk mencegah penularan melalui droplet, masker bedah (masker datar) diberikan kepada pasien untuk dipakai sesering mungkin.

h. Orang yang memberikan perawatan sebaiknya menggunakan masker bedah terutama jika berada dalam satu ruangan dengan pasien.

i. Hindari kontak langsung dengan cairan tubuh terutama cairan mulut atau pernapasan (dahak, ingus dan lain-lain) dan tinja.

j. Jangan gunakan masker atau serung tangan yang telah terpakai.

k. Sediakan sprei dan alat makan khusus untuk pasien.

1. Bersihkan permukaan di sekitar pasien termasuk toilet dan kamar mandi secara teratur.

m. Bersihkan pakaian pasien, sprei, handuk, dan lain-lain menggunakan sabun cuci rumah tangga dan air atau menggunakan mesin cuci dengan suhu air $60-90^{\circ} \mathrm{C}$ dengan detergen dan keringkan.

n. Sarung tangan dan apron plastik sebaiknya digunakan saat membersihkan permukaan pasien, baju atau bahan-bahan lain yang terkena cairan tubuh pasien..

o. Sarung tangan, masker, dan bahan-bahan sisa lain selama perawatan harus dibuang di tempat sampah dalam ruangan pasien yang kemudian ditutup rapat sebelum dibuang sebagai kotoran infeksius.

p. Hindari kontak dengan barang-barang terkontaminasi lainnya seperti sikat gigi, alat makan-minum, handuk, pakaian, dan sprei.

q. Ketika petugas kesehatan memberikan pelayanan kesehatan rumah, selalu perhatikan APD dan ikuti rekomendasi pencegahan penularan penyakit melalui droplet.

\section{Efektivitas Pembelajaran Jarak Jauh}

\section{Pengertian Efektifitas Pembelajaran}

Menurut Miarso (Rohmawati, 2015:16) "efektivitas pembelajaran merupakan salah satu standar mutu pendidikan dan sering kali diukur dengan tercapainya tujuan, atau dapat juga diartikan sebagai ketepatan dalam mengelola suatu situasi, "doing the right things"." Sedangkan Sadiman mengatakan (1987) (Al-Tabany, 2017:21) "keefektifan pembelajaran adalah hasil guna yang diperoleh setelah pelaksanaan proses belajar mengajar." Hamalik (Rohmawati, 2015:16) menyatakan bahwa "pembelajaran yang efektif adalah pembelajaran yang menyediakan kesempatan belajar sendiri atau melakukan aktivitas seluas-luasnya kepada siswa untuk belajar." Berdasarkan pengertian di atas dapat disimpulkan bahwa efektivitas pembelajaran adalah satu standar mutu pendidikan dan sering kali diukur dengan tercapainya tujuan, yang diperoleh setelah pelaksanaan proses belajar mengajar, yang menyediakan kesempatan belajar sendiri atau melakukan aktivitas seluas-luasnya kepada siswa untuk belajar.

\section{Syarat Utama Keefektifan Pembelajaran}

Menurut Soemosasmito (Al-Tabany, 2017:22) suatu pembelajaran dikatakan efektif apabila memenuhi persyaratan utama keefektifan pengajaran, yaitu :

a. Presentasi waktu belajar siswa yang tinggi dicurahkan terhadap KBM;

b. Rata-rata perilaku melaksanakan tugas yang tinggi di antara siswa;

c. Ketetapan antara kandungan materi ajaran dengan kemampuan siswa (orientasi keberhasilan belajar) diutamakan; dan 
d. Mengembangkan suasana belajar yang akrab dan positif, mengembangkan struktur kelas yang mendukung butir $\mathrm{b}$, tanpa mengabaikan butir $\mathrm{d}$.

\section{Ciri-ciri Keefektifan Program Pembelajaran}

Keefektifan program pembelajaran menurut Surya (Firdaus, 2016:64) ditandai dengan ciri-ciri sebagai berikut :

a. Berhasil menghantarkan siswa mencapai tujuan-tujuan instruksional yang telah ditetapkan.

b. Memberikan pengalaman belajar atraktif, melibatkan siswa secara aktif sehingga menunjang pencapaian tujuan instruksional.

c. Memiliki sarana-sarana yang menunjang proses belajar mengajar.

\section{Pembelajaran Jarak Jauh}

Menurut Dogmen (Rahmawati, 2020:414) "pembelajaran jarak jauh adalah pembelajaran yang menekankan pada cara belajar mandiri (self study). Belajar mandiri diorganisasikan secara sistematis dalam menyajikan materi pembelajaran, pemberian bimbingan kepada pembelajar, dan pengawasan untuk keberhasilan belajar pembelajar." Menurut Munir (2012:16) "pembelajaran jarak jauh adalah ketika proses pembelajaran tidak terjadinya kontak dalam bentuk tatap muka langsung antara pengajar dan pembelajar. Komunikasi berlangsung dua arah yang dijembatani dengan media seperti komputer, televisi, radio, telepon, internet, video dan sebagainya". Kearsly, Moore (Yerusalem, dkk, 2020:483) mengemukakan : Pembelajaran jarak jauh adalah belajar yang direncanakan di tempat lain atau di luar tempatnya mengajar. Oleh karena itu, diperlukan teknik-teknik khusus dalam mendesain materi pembelajaran, teknik-teknik khusus pembelajaran, metodologi khusus komunikasi melalui berbagai media, dan penataan organisasi serta administrasi yang khusus pula.

Berdasarkan pengertian diatas dapat disimpulkan bahwa pembelajaran jarak jauh adalah pembelajar yang direncanakan di tempat lain atau di luar tempatnya mengajar danketika proses pembelajaran tidak terjadi tatap muka langsung antara pengajar dan pembelajar. Sehingga pembelajaran menekankan pada pembelajaran mandiri (self study), dan menggunakan teknik-teknik khusus dalam mendesain materi pembelajaran seperti penataan organisasi, administrasi dan metodologi khusus komunikasi melalui berbagai media sepertikomputer, televisi, radio, telepon, internet, video dan sebagainya.

\section{Ragam Proses Belajar Pendidikan Jarak Jauh}

Menurut (Yerusalem,dkk, 2020:484) ragam proses belajar pendidikan jarak jauh sebagai berikut :

a. Belajar mandiri

b. Belajar terbimbing/terstruktur

c. Tutorial tatap muka: proses pembelajaran jarak jauh dilaksanakan dengan mempersyaratkan adanya tutorial/pembimbingan tatap muka langsung (atau termediasi sinkron) kepada peserta didik untuk beragam mata kuliah.

d. Tutorial elektronik

e. Bantuan lainnya (koresponden, telepon, dan faksimile).

\section{Prinsip Pelaksanaan Pembelajaran Jarak Jauh}

Menurut Munir (2012:24) prinsip pelaksanaan pembelajaran jarak jauh sebagai berikut:

a. Tujuan yang jelas

b. Relevan dengan kebutuhan 
c. Mutu pendidikan

d. Efisien dan efektivitas program

e. Pemerataan dan perluasan kesempatan belajar

f. Kemandirian

g. Keterpaduan

h. Kesinambungan

\section{Karakteristik atau Ciri-ciri Pembelajaran Jarak Jauh}

Menurut Munir (2012:25) karakteristik atau ciri-ciri pembelajaran jarak jauh sebagai berikut:

a. Program disusun disesuaikan jenjang, jenis, dan sifat pendidikan.

b. Dalam proses pembelajaran tidak ada pertemuan langsung secara tatap muka antara pengajar dan pembelajar, sehingga tidak ada kontak langsung antara pengajar dengan pembelajar.

c. Pembelajar dan pengajar terpisah sepanjang proses pembelajaran itu karena tidak ada tatap muka seperti halnya dalam pembelajaran konvensional, sehingga pembelajar harus dapat belajar secara mandiri.

d. Adanya lembaga pendidikan yang mengatur pembelajar untuk belajar mandiri. Pendidikan jarak jauh adalah sistem pendidikan yang menekankan pada cara belajar mandiri (self study).

e. Lembaga pendidikan merancang dan menyiapkan materi pembelajaran, serta memberikan pelayanan bantuan belajar kepada pembelajar.

f. Materi pembelajaran disampaikan melalui media pembelajaran, seperti komputer dengan internetnya atau dengan program e-learning.

g. Melalui media pembelajaran tersebut, akan terjadi komunikasi dua arah (interaktif) antara pembelajar dan pengajar, pembelajar dengan pembelajar lain, atau pembelajar dengan lembaga penyelenggara pembelajaran jarak jauh.

h. Tidak ada kelompok belajar yang bersifat tetap sepanjang masa belajarnya, karena itu pembelajar menerima pembelajaran secara individual bukannya secara kelompok.

i. Paradigma baru yang terjadi dalam pembelajaran jarak jauh adalah peran pengajar yang lebih bersifat fasilitator yang memberikan bantuan atau kemudahan kepada pembelajar untuk belajar, dan pembelajar sebagai peserta dalam proses pembelajaran.

j. Pembelajar dituntut aktif, interaktif, dan partisipatif dalam proses belajar, karena sistem belajarnya secara mandiri yang sedikit sekali mendapatkan bantuan dari pengajar atau pihak lainnya.

k. Sumber belajar adalah bahan-bahan yang dikembangkan secara sengaja sesuai kebutuhan dengan tetap berdasarkan kurikulum.

1. Interaksi pembelajaran bisa dilaksanakan secara langsung jika ada suatu pertemuan.

\section{METHODS}

Metode penelitian yang digunakan oleh peneliti adalah metode kualitatif yang sifatnya deskriptif yang artinya penelitian yang mengacu pada teknik pengumpulan data yang dilakukan dengan wawancara mendalam dengan key informan dan informan. Datadata yang disajikan dalam penelitian kualitatif berupa kata-kata bukan berupa angkaangka.Data tersebut harus berupa kata-kata tertulis yang dapat mendeskripsikan serta memaparkan secara terperinci hasil dari penelitian atau wawancara mendalam 
tersebut.Analisis yang digunakan dalam penelitian ini menekankan pada bagaimana efektivitas pembelajaran jarak jauh pada masa pandemi covid 19.

\section{Tehnik pengolahan data}

Teknik analisis data yang digunakan dalam penelitian ini adalah analisis data kualitatif, mengikuti konsep yang diberikan Miles and Huberman dan Spradley. Miles and Huberman (Sugiyono, 2013:183) mengemukakan bahwa aktivitas dalam analisis data kualitatif dilakukan secara interaktif dan berlangsung secara terus menerus pada setiap tahapan penelitian sehingga sampai tuntas, dan datanya sampai jenuh. Aktivitas dalam analisis data, yaitu data reduction, data display, dan conclusion drawing/verification. Langkah-langkah analisis ditunjukkan pada gambar berikut.

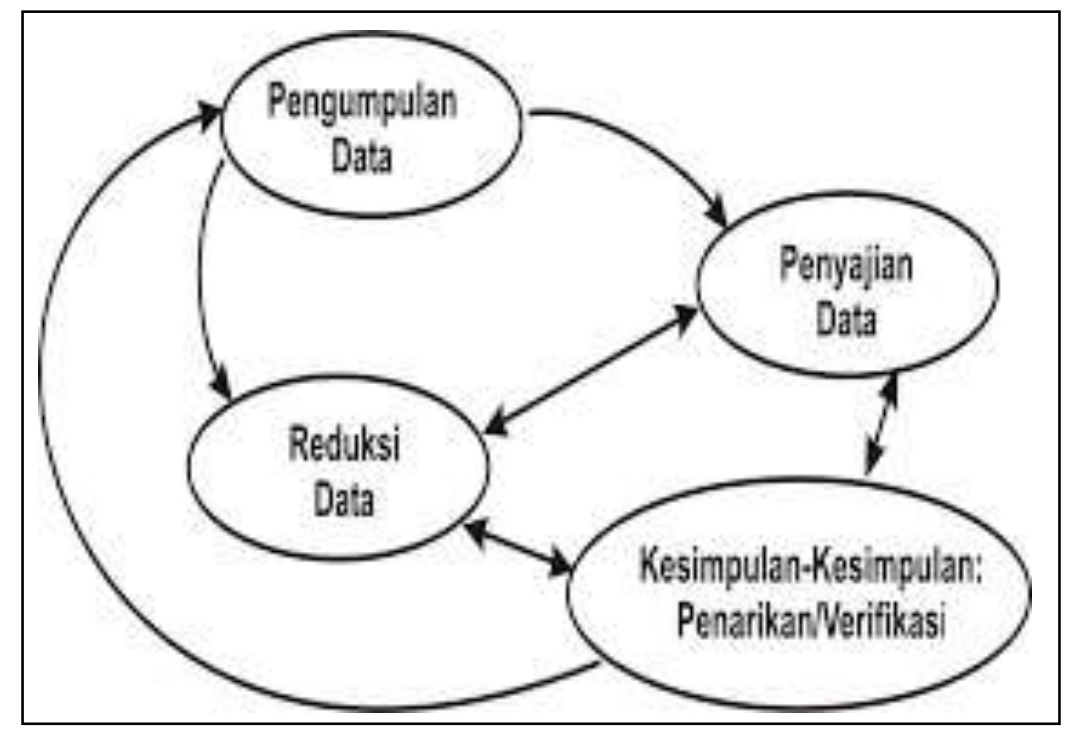

Sumber :Sugiyono (2013:183)

Gambar 1.

Komponen dalam AnalisisData (interactive model)

Selanjutnya menurut Spradley teknik analisis data disesuaikan dengan tahapan dalam penelitian. Pada tahap penjelajahan dengan teknik pengumpulan data grand tour question, analisis data dilakukan dengan analisis domain.Pada tahap menentukan fokus analisis data dilakukan dengan analisis taksonomi. Pada tahap selection, analisis data dilakukan dengan analisis komponensial. Selanjutnya untuk sampai menghasilkan judul dilakukan dengan analisis tema.

\section{Pengujian Kredibilitas Data}

Menurut Sugiyono (2013:184) pengujian kredibilitas data penelitian akan dilakukan dengan cara:

1. Perpanjangan pengamatan

Dengan perpanjangan pengamatan berarti peneliti kembali ke lapangan, melakukan pengamatan, wawancara lagi dengan sumber data yang pernah ditemui maupun yang baru.

2. Meningkatkan ketekunan

Meningkatkan ketekunan berarti melakukan pengamatan secara lebih cermat dan berkesinambungan. 
3. Trianggulasi

Trianggulasi dilakukan dengan caratrianggulasi teknik, sumber data dan waktu. Trianggulasi teknik dilakukan dengan cara menanyakan hal yang sama dengan teknik yang berbeda, yaitu dengan wawancara, observasi, dan dokumentasi.

4. Member check (pengecekan anggota)

Member check adalah proses pengecekan data yang diperoleh peneliti kepada pemberi data. Tujuan member check adalah untuk mengetahui seberapa jauh data uang diperoleh sesuai dengan apa yang diberikan oleh pemberi data.

\section{RESULTS \& DISCUSSION}

\section{Hasil Penelitian}

Merujuk pada temuan yang peneliti dapatkan di lapangan dengan menggunakan teknik wawancara kepada 15 informan (remaja SMP dan SMA Rumah Al-Qaswa). Didapatkan temuan yang dapat menjawab rumusan masalah yang telah dipaparkan pada bab 1 mengenai "Bagaimana efektivitas pembelajaran jarak jauh pada masa pandemi covid 19 pada siswa tingkat SMP dan SMA di Rumah Al-Qaswa". Berikut adalah hasil wawancara terhadap 13 responden dengan teknik wawancara.

Tabel 1.

Hasil Jawaban Responden dengan Teknik Wawancara

\begin{tabular}{|c|l|c|c|c|c|c|c|}
\hline \multirow{2}{*}{$N$} & \multirow{2}{*}{ NO NAMA } & \multicolumn{7}{c|}{ PERTANYAAN } \\
\cline { 3 - 8 } & & $\mathbf{1}$ & $\mathbf{2}$ & $\mathbf{3}$ & $\mathbf{4}$ & $\mathbf{5}$ & $\mathbf{6}$ \\
\hline 1 & M. IBNU ZIDANE & YA & YA & YA & YA & TIDAK & YA \\
\hline 2 & AHMAD ZAKI & YA & TIDAK & YA & YA & TIDAK & TIDAK \\
\hline 3 & DIAN UTAMI W & TIDAK & TIDAK & YA & YA & TIDAK & TIDAK \\
\hline 4 & M. REZA FIRDAUS & YA & YA & YA & YA & YA & YA \\
\hline 5 & SITI AISYAH & TIDAK & YA & YA & YA & TIDAK & YA \\
\hline 6 & YULI AMALIA PUTRI & TIDAK & YA & YA & YA & YA & YA \\
\hline 7 & IRMA AQILAH & YA & YA & YA & YA & TIDAK & YA \\
\hline 8 & NURJANAH & YA & YA & YA & YA & TIDAK & YA \\
\hline 9 & MAYSARAH NI'MAH & TIDAK & YA & YA & YA & TIDAK & TIDAK \\
\hline 10 & SULTAN FADHLI & TIDAK & YA & YA & YA & YA & TIDAK \\
\hline 11 & ILHAM MAULANA & YA & YA & YA & YA & YA & YA \\
\hline 12 & M. ADSYAH RAZAQ & TIDAK & YA & TIDAK & TIDAK & TIDAK & YA \\
\hline 13 & MUHAMMAD PAHRI & TIDAK & TIDAK & TIDAK & TIDAK & TIDAK & YA \\
\hline 14 & JASMINE SITI HUMAIROH & YA & YA & YA & YA & TIDAK & YA \\
\hline 15 & MUHAMMAD THORIQ & TIDAK & YA & TIDAK & TIDAK & TIDAK & YA \\
\hline
\end{tabular}

\begin{tabular}{|c|l|}
\hline \multicolumn{2}{|l|}{ BUTIR WAWANCARA } \\
\hline 1 & APAKAH ANDA MUDAH MEMAHAMI MATERI PEMBELAJARAN ONLINE YANG DIBERIKAN OLEH GURU \\
\hline 2 & APAKAH ANDA PUAS DENGAN PEMBELAJARAN YANG TELAH DILAKSANAKAN OLEH PARA GURU \\
\hline 3 & INTERAKSI ANDA DENGAN GURU BAIK SAAT MELAKUKAN PEMBELAJARAN ONLINE/JARAK JAUH \\
\hline 4 & SECARA UMUM PEMBELAJARAN YANG DILAKSANAKAN OLEH SEBAGIAN BESAR GURU MENYENANGKAN \\
\hline 5 & MASING-MASING GURU MENGGUNAKAN APLIKASI PEMBELAJARAN YANG BERBEDA \\
\hline 6 & SEKOLAH MEMILIKI WEBSITE KHUSUS UNTUK PEMBELAJARAN ONLINE \\
\hline
\end{tabular}

Sumber : Diolah Peneliti, (2020) 
1. Jawaban butir wawancara 1

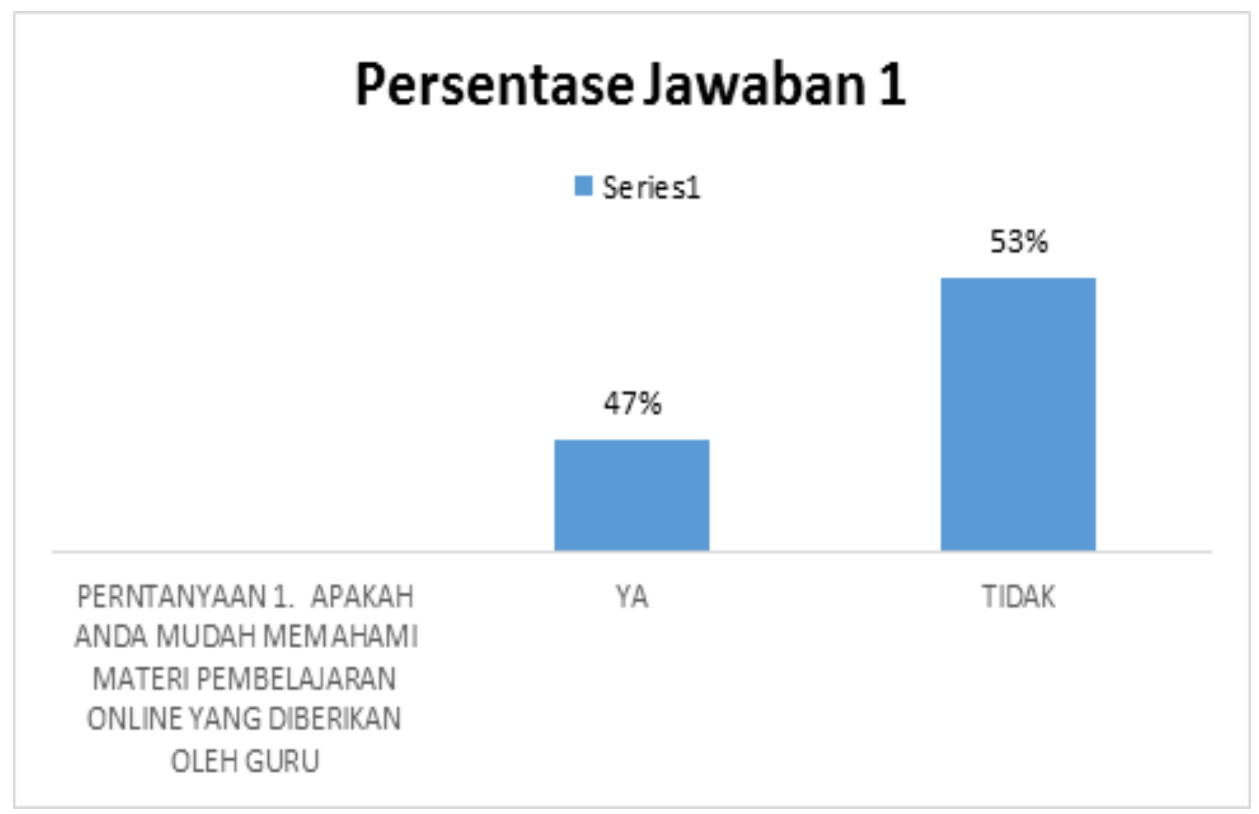

Sumber: Diolah Peneliti, (2020)

Gambar 2.

Hasil Jawaban Responden (1)

Temuan pada penelitian ini menggambarkan bahwa pada pemberian materi yang diberikan oleh guru dengan pembelajaran jarak jauh saat inisebagian besar belum dipahami oleh para remaja usia sekolah. Ini terbukti dari besarnya persentase yang menyatakan $53 \%$ responden merasa tidak memahami materi pembelajaran online yang diberikan oleh guru. Sedangkan $47 \%$ responden merasa mudah memahami materi pembelajaran yang dilakukan secara online.

Dari nilai diatas, diperoleh keterangan lebih lanjut bahwasiswa lebih mudah memahami materi pembelajaran langsung/tatap muka karena penyampaian materi pembelajaran yang disampaikan secara langsung oleh guru lebih jelas, detail, mudah untuk dipahami, dan kalau ada materi yang kurang dipahami dapat langsung berinteraksi dengan guru melalui tanya jawab dengan guru. Responden yang merasa tidak memahami materi pembelajaran secara online beranggapan bahwa mereka merasa sulit untuk melakukan interaksi dengan guru tentang materi pembelajaran yang tidak bisa dimengerti dengan cara membaca saja. Mereka beranggapan pada saat di sekolah, guru dapat menyampaikan materi secara langsung melalui tatap muka di kelas dan lebih mudah melakukan interaksi antara guru dan murid. Sementara pada pembelajaran jarak jauh saat ini, penyampaian materi pembelajaran dari guru kurang dipahami oleh siswa karena tidak ada bimbingan belajar secara langsung, tidak bisa melakukan diskusi bersama pada pelajaran yang sulit dimengerti, dan juga karena waktu pembelajaran yang tidak terukur dibandingkan dengan pembelajaran konvensional.

Dari persentase $47 \%$ responden yang merasa mudah memahami materi dengan pembelajaran jarak jauh. Didapatkan alasan bahwa mereka lebih mudah memahami materi pembelajaran melalui jarak jauh dari rumah, karena pada saat mereka melakukan proses pembelajaran jarak jauh, umumnya mereka akan ditemani orang tua, dan kalau ada materi pembelajaran yang tidak dipahami mereka akan bertanya kepada orang tua, jadi siswa merasa menjadi lebih dekat dengan orang tua.Responden yang merasa memahami materi dengan pembelajaran jarak jauh saat ini umumnya dikarenakan mereka tidak menyukai proses pembelajaran yang dilaksanakan dari sekolah karena merasa jenuh dan 
waktu pembelajaran di sekolah yang panjang, sedangkan mereka lebih menyukai pembelajaran yang dilakukan melalui jarak jauh dari rumah karena waktu yang lebih singkat dibandingkan dengan pembelajaran yang dilakukan secara konvensional di sekolah.

2. Jawaban butir wawancara 2

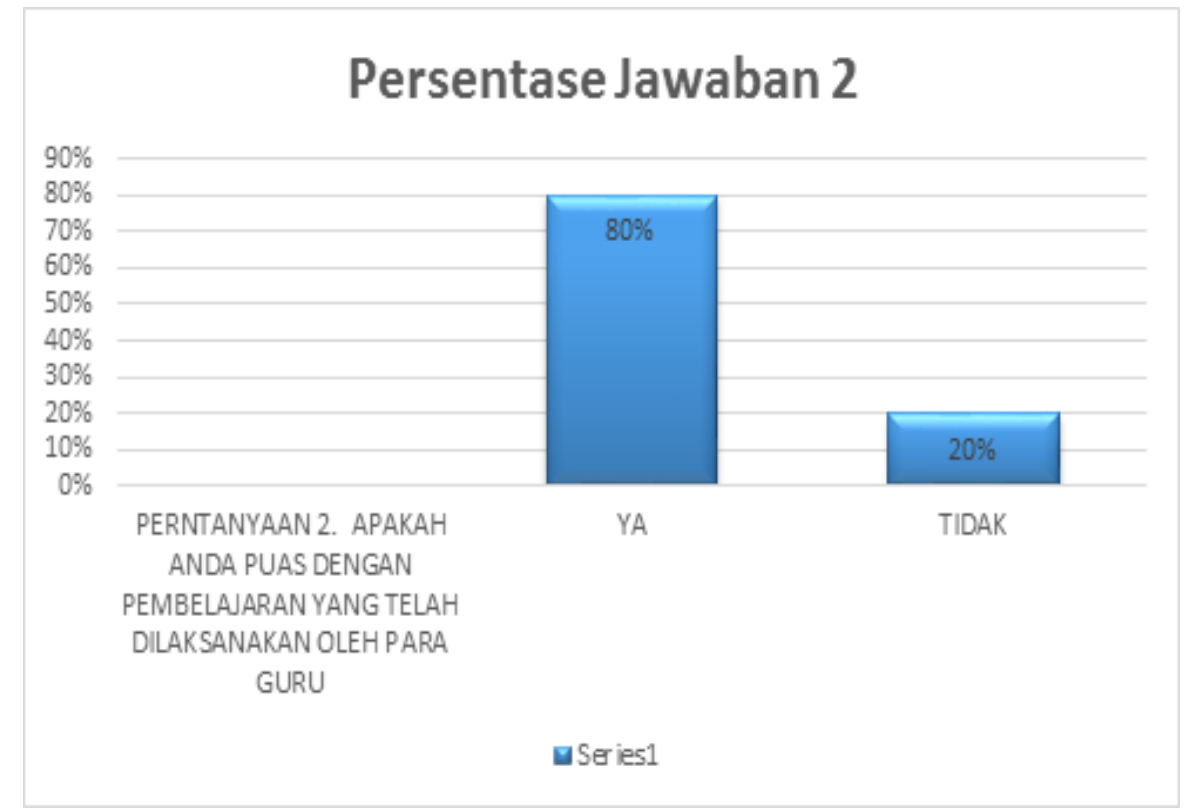

Sumber: Diolah Peneliti, 2020

Gambar 3.

Hasil Jawaban Responden (2)

Temuan pada penelitian ini menggambarkan bahwa pelaksanaan pembelajaran jarak jauh yang dilaksanakan pada saat ini cukup disenangim oleh para remaja. Ini terbukti dari besarnya persentase $80 \%$ yang menyatakan puas dengan pembelajaran yang dilaksanakan oleh guru dan hanya $20 \%$ saja yang merasa tidak puas dengan kondisi pembelajaran jarak jauh saat ini.

Responden yang merasa puas dengan pembelajaran jarak jauh saat ini beranggapan bahwa para guru sangat berupaya memberikan kemudahan dalam melaksanakan pembelajaran jarak jauh dan sebisa mungkin meminimalkan hambatan-hambata yang menyebabkan siswa merasa terbebani dengan pembelajaran jarak jauh tersebut. Sementara pada remaja yang merasa tidak puas beranggapan bahwa dalam prakteknya guru terliohat asal dalam melaksanakan pembelajaran jarak jauh, hal ini terlihat dari hasil wawancara dengan nara sumber yang menjelaskan bahwa guru hanya memberikan tugas saja pada setiap pelaksanaan kegiatan pembelajaran jarak jauh

Temuan lain pada penelitian ini juga menggambarkan bahwa siswa lebih mudah memahami materi dari sekolah dibandingkan melalui pembelajaran jarak jauh. Bukti tersebut dapat dilihat pada gambar digram berikut mengenai pernyataan siswa tentang lebih mudah memahami materi di sekolah atau melalui pembelajaran jarak jauh. 
3. Jawaban butir wawancara 3

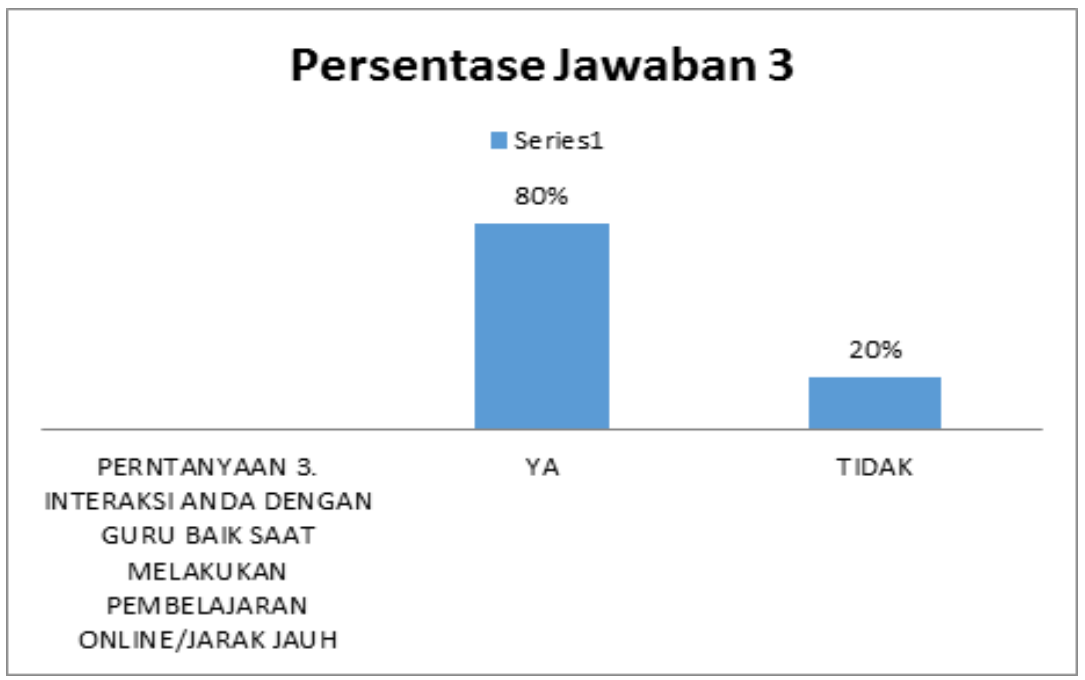

Sumber: Diolah Peneliti, (2020)

Gambar 4.

Hasil Jawaban Responden (3)

Data di atas menggambarkan bahwa $80 \%$ responden menyatakan bahwa dalam pembelajaran jarak jauh ini terjadi interaksi antara guru dan siswa, seperti guru memberikan ruang untuk melakukan tanya jawab tentang materi pembelajaran, dan siswa diberikan kesempatan untuk mengemukakan pendapat. Sementara $20 \%$ responden lainnya menyatakan jarang melakukan interaksi dengan guru dan menyatakan tidak ada interaksi dengan guru selama melakukan pembelajaran jarak jauh. Sehingga apabila siswa ada yang tidak mengerti dengan materi pembelajaran yang diberikan maka siswa akan mencari jawabannya melalui Google atau buku.

4. Jawaban butir wawancara 4

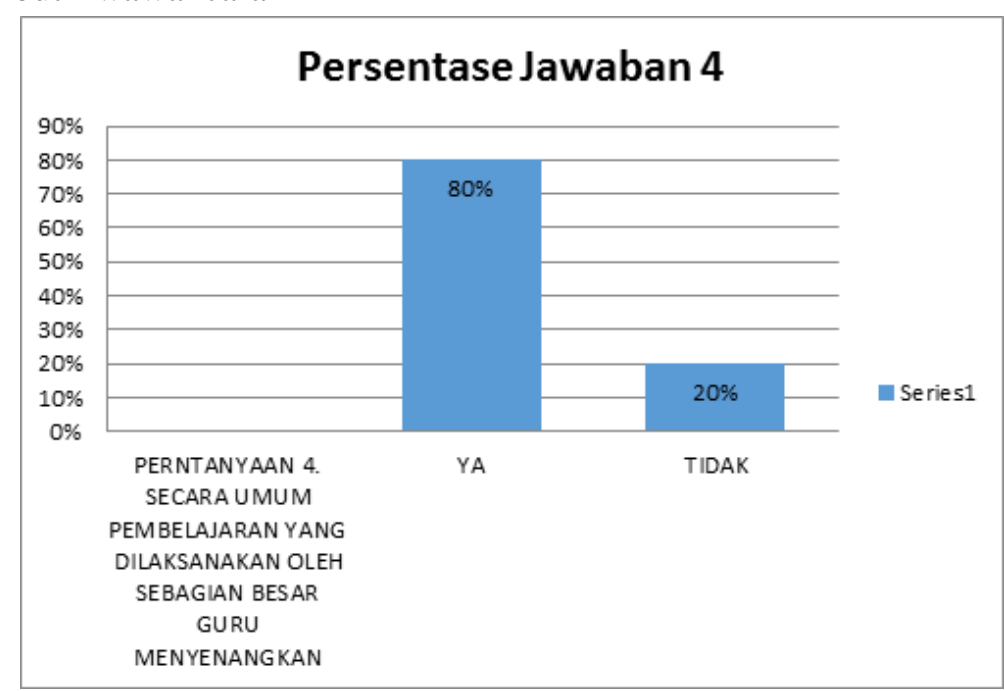

Sumber: Diolah Peneliti, 2020

Gambar 5.

Hasil Jawaban Responden (4)

Data diatas menunjukkan bahwa sebagian besar responden menyatakan bahwa secara umum pembelajaran yang dilaksanakan oleh para guru dimasa pandemi ini cukup 
menyenangkan. Hal ini dapat dilihat dari besarnya persentase jawaban "Ya" (80\%) pada pertanyaan apakah pembelajaran yang dilaksanakan oleh sebagian besar guru menyenangkan atau tidak. Sementara hanya $20 \%$ saja yang menyatakan tidak. Dari persentase jawab ya diatas, setidaknya dapat menggambarkan meskipun pembelajaran jarak jauh faktanya memang terjadi dengan terpaksa, namun para guru masih dapat diandalkan kreativitasnya dalam menciptakan pembelajaran yang masih disenangi oleh para siswa meskipun harus belajar dengan jarak jauh.

\section{Jawaban butir wawancara 5}

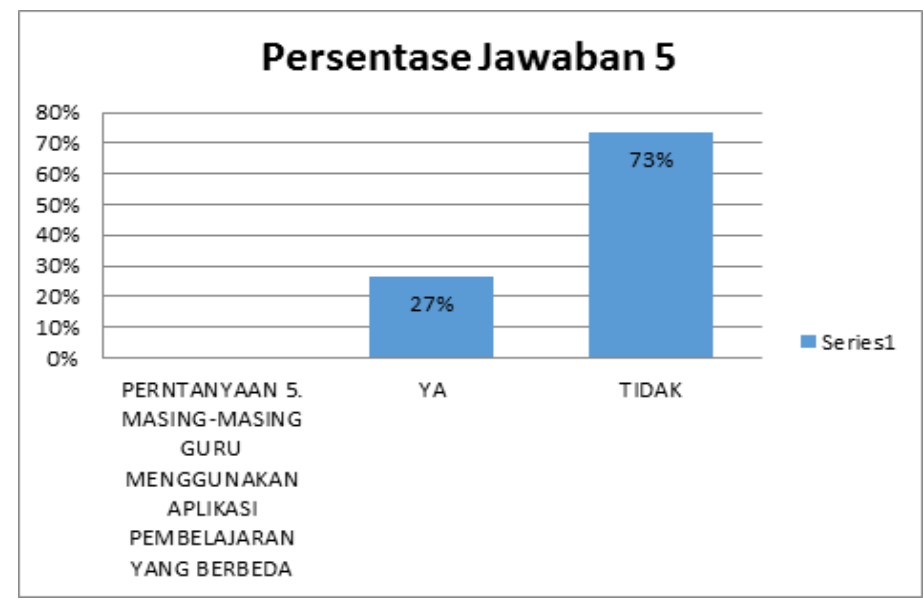

Sumber: Diolah Peneliti, 2020

\section{Gambar 6.}

Hasil Jawaban Responden (5)

Hasil pertanyaan wawancara ke-5 menyimpulkan bahwa dari 15 responden, $73 \%$ responden menjawab bahwa semua guru menyampaikan materi pembelajaran dengan jarak jauh menggunakan web atau aplikasi yang sama. Sedangkan $27 \%$ responden menjawab bahwa setiap guru mempunyai cara menyampaikan materi dengan web atau aplikasi berbeda-beda sesuai dengan kebutuhan dari guru untuk menyampaikan materi pembelajaran, ada yang menggunakan Quizizz, Google Clasroom, Zoom, WhatsApp, Edmodo, Google Meet, dan Google Forms.

6. Jawaban butir wawancara 6

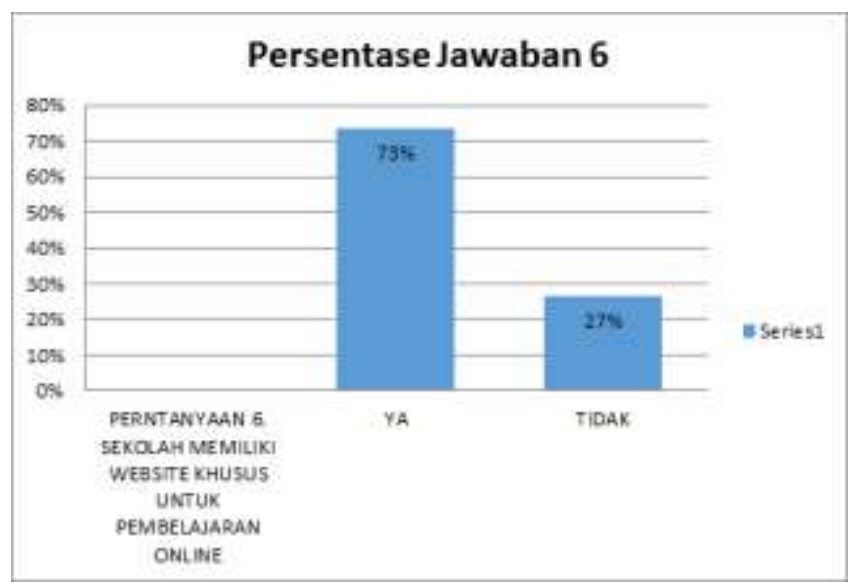

Sumber: Diolah Peneliti, 2020

Gambar 7.

Hasil Jawaban Responden (6) 
7. Persepsi remaja mengenai masalah utama kesulitan dalam pembelajaran jarak jauh

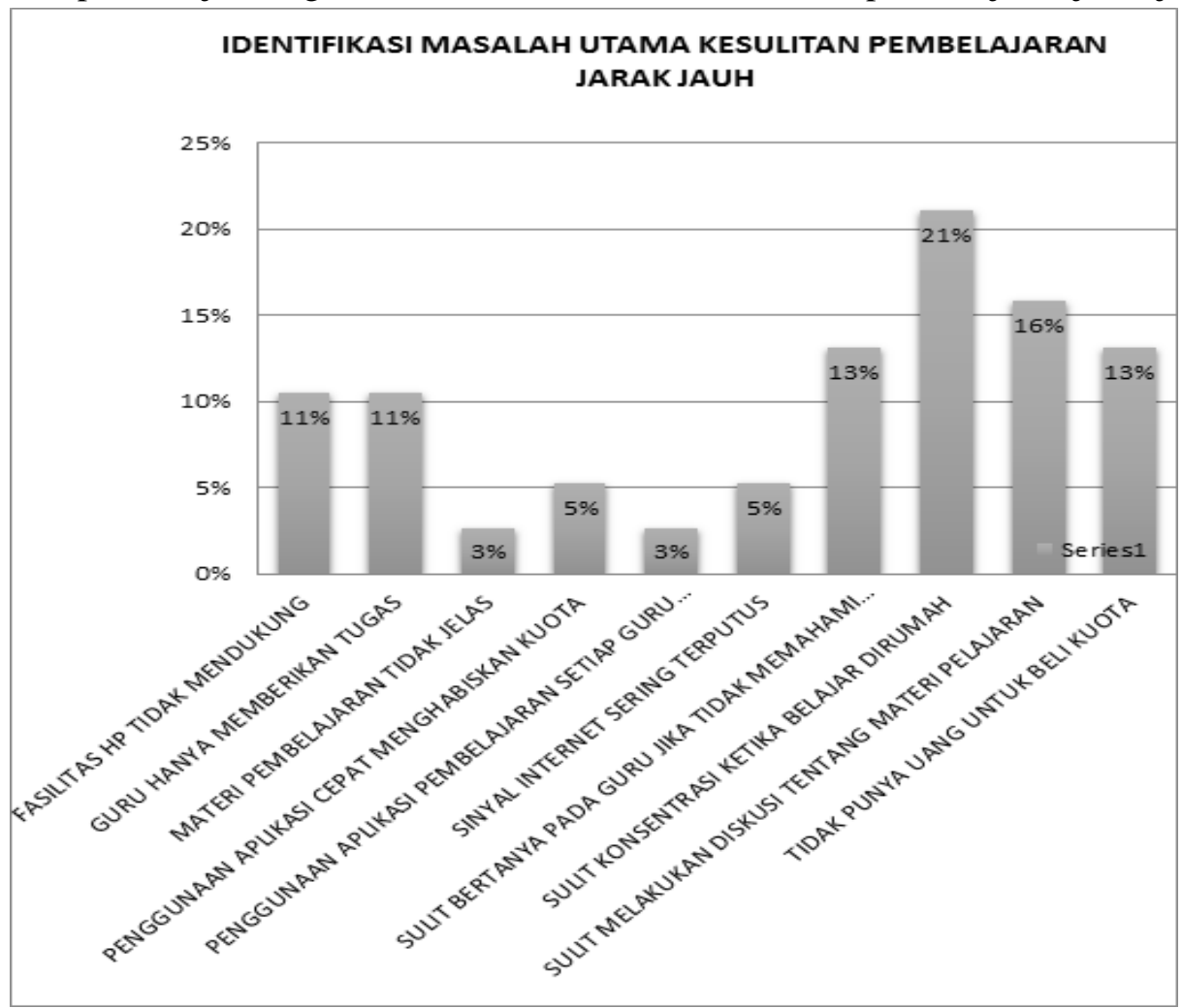

Sumber: Diolah Peneliti, 2020

Gambar 8.

Masalah Utama Kesulitan Pembelajaran Jarak Jauh

Data diatas merupakan hasil identifikasi masalah utama yang pada kesulitan belajar jarak jauh berdasarkan persepsi remaja. Dapat disimpulkan bahwa masalah utama dari kesulitan pembelajaran jarak jauh terletak pada sulitnya para remaja berkonsentrasi saat belajar dirumah (21\%), sementara urutan kedua masalah utamanya adalah sulit melakukan diskusi tentang materi pelajaran (16\%), urutan ketiga adalah tidak punya uang untuk beli kuota (13\%), keempat sulit bertanya jika tidak memahami materi (13\%), kelima guru hanya memberikan tugas $(11 \%)$, keenam fasilitas hp tidak mendukung (11\%), ketujuh sinyalnya sering terputus (5\%), kedelapan aplikasi yang digunakan cepat menghabiskan kuota (5\%), kesembilan materi pelajaran tidak jelas (3\%), kesepuluh aplikasi yang digunakan guru berbeda-beda (3\%).

\section{Pembahasann}

Adanya wabah Virus Corona atau Novel-Corona Virus, disingkat 2019-nCoV yang pertama kali diidentifikasi di tengah merebaknya kasus penyakit infeksi paru atau pneumonia di kota Wuhan, provinsi Hubie, Cina. Kemudian dinyatakan sebagai keadaan darurat dunia (pandemi) atau global outbreak oleh Organisasi Kesehatan Dunia (WHO) pada 30 Januari 2020. WHO memberi nama penyakit infeksi virus ini sebagai Covid-19 (Corona Virus Disease-2019). Diluar Cina, peta persebaran virus ini telah terjadi di banyak negara, Covid-19 telah merambah lebih dari 200 negara di seluruh dunia. Sejumlah kematian pun telah dilaporkan.

Dampak pandemi Covid-19 di Indonesia telah membuat sistem pembelajaran berubah secara drastis dari pembelajaran tatap muka menjadi pembelajaran jarak jauh. Sejak munculnya kasus pasien positif Covid-19 di Indonesia, Pemerintah melalui 
Kementerian Pendidikan dan Kebudayaan dan Kementerian Agama Republik Indonesia, menerapkan kebijakan belajar dan bekerja dari rumah sejak pertengahan Maret 2020. Hal ini dilakukan sebagai upaya mencegah meluasnya penularan virus corona. Diharapkan dengan seluruh lembaga pendidikan tidak melaksanakan aktivitas seperti biasanya, hal ini dapat meminimalisir menyebarnya penyakit covid 19 ini.

Pembelajaran jarak jauh dirancang untuk melayani pembelajar dalam yang besar dengan latar belakang pendidikan, usia, dan tempat tinggal yang beragam. Dengan demikian pembelajaran jarak jauh untuk mengatasi batasan jarak, tempat serta waktu dalam melaksanakan proses pembelajaran. Oleh karena itu, pembelajaran jarak jauh memiliki karakteristik atau ciri yang khas berbeda dengan sistem pendidikan yang diselenggarakan secara konvensional secara tatap muka. Karakteristik itu adalah terpisahnnya secara fisik antara aktivitas pengajar dan pembelajar dan tidak ada tatap muka secara langsung, sehingga terjadi keterbatasan proses pembelajaran.

Penelitian ini menjawab meskipun pembelajaran jarak jauh yang diselenggrakan oleh banyak satuan pendidikan di Indonesia ini, terkesan mendadak dan tidak siap. Namun temuan dari peelitian ini menyimpulkan bahwa penyelenggaraan pembelajaran jarak jauh yang diselenggarakan sejauh ini masih terbilang efektif hal ini dapat dilihat dari besarnya prosentase jawaban yang mengarah kepada jawaban positif sebagian besar remaja yang berstatus pelajar mengenai penyelenggaraan dan uapay yang dilakukan oleh para guru dan lembaga pendidikan ketika melakukan pembelajaran jarak jauh.

Namun perlu juga diketahui, meskipun penelitian ini menyimpulkan penyelenggaraan pembelajaran jarak jauh masih terbilang efektif. Identifikasi dilapangan membuktikan ada banyak masalah utama yang dirasakan oleh siswa saat melakukan pembelajaran jarak jauh. Terbukti dari hasil 38 jawaban wawancara yang menyebutkan bahwa $21 \%$ responden mengatakan sulit berkonsentrasi ketika melaksanakan pembelajaran dirumah. Hal ini sangat wajar karena dari hasil pengamatan dan pendalaman lebih lanjut, hampir semua responden yang diwawancarai berasal dari keluarga menengah kebawah dengan penghasilan dibawah standar sejahtera. Sehingga dengan kondisi tersebut, bisa digambarkan bahwa lingkungan dan iklim tempat tinggal mereka, tidak cukup besar, dan tidak memungkinkan untuk berkonsentrasi saat melakukan pembelajaran dirumah.

Sementara masalah utama kedua dengan prosentase $16 \%$ adalah sulitnya mereka berdiskusi mengenai materi pembelajaran. Hal ini tentu sangat wajar dikarenakan ada beberapa matapelajaran eksakta yang tidak mungkin dapat dipelajari hanya dengan membaca. Namun, mata pelajaran tersebut sangat mengharuskan guru untuk memberi ruang diskusi khusus ketika siswa mengalami kesulitan untuk memecahkan sebuah kasus dari materi yang dibahas. Atau mata pelajaran yang bersifat praktikum yang tidak dapat dilakukan secara online $100 \%$.

Oleh karenanya, sangat diperlukan terobosan-terobosan kreatif dan inovatif yang harus bisa dipecahkan oleh para pemangku kepentingan agar masalah utama diatas dapat terpecahkan dengan baik. Selain itu, teridentifikasi juga masalah utama lain yang menyebabkan kesulitan belajar seperti tidak punya uang untuk beli kuota (13\%), sulit bertanya jika tidak memahami materi (13\%), guru hanya memberikan tugas (11\%), fasilitas hp tidak mendukung (11\%), sinyalnya sering terputus (5\%), aplikasi yang digunakan cepat menghabiskan kuota (5\%), materi pelajaran tidak jelas (3\%), aplikasi yang digunakan guru berbeda-beda (3\%).

Dari hasil data diatas dapat dilihat secara sederhana masalah utama kesulitan PJJ yang disajikan dalam diagram fishbone berikut ini : 


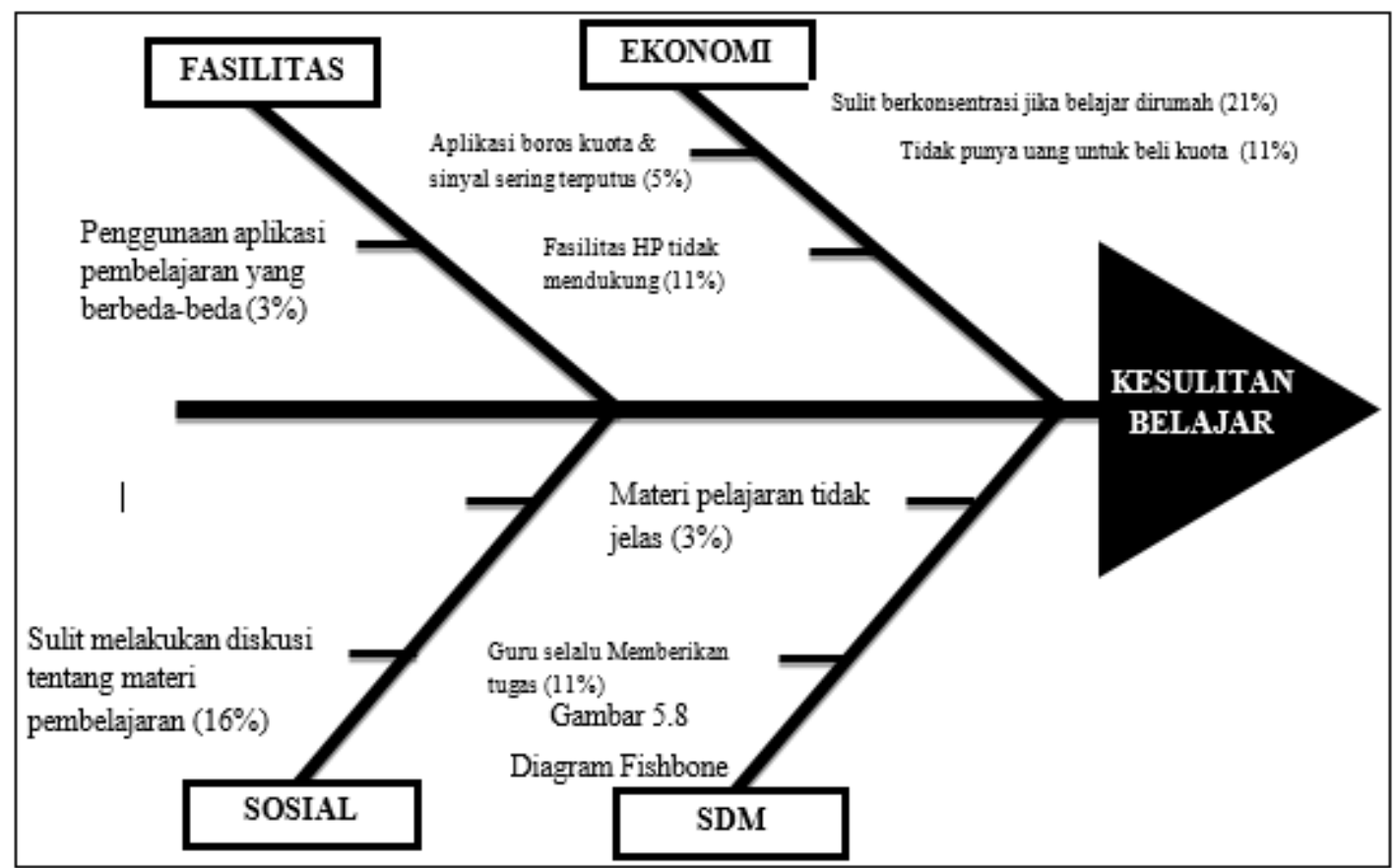

Sumber : Peneliti, (2020)

Gambar 9.

Diagram Fishbone

\section{CONCLUSION}

\section{Simpulan}

Berdasarkan hasil penelitian yang diperoleh maka dapat disimpulkan bahwa dampak dari pandemi covid-19 saat ini memberikan kontribusi cukup besar pada dunia pendidikan, karena dengan mewabahnya covid-19 ini kegiatan belajar mengajar yang biasanya dilakukan secara konvensional diubah menjadi pembelajaran jarak jauh dari rumah. Sesuai dengan Surat Edaran (SE) yang dikeluarkan Menteri Pendidikan dan Kebudayaan Republik Indonesia pada 24 Maret 2020 tentang pelaksanaan kebijakan pendidikan dalam masa darurat penyebaran covid, dalam Surat Edaran tersebut dijelaskan bahwa proses belajar dilaksanakan di rumah melalui pembelajaran daring/jarak jauh dilaksanakan untuk memberikan pengalaman belajar yang bermakna bagi siswa.

Fakta yang ditemukan dilapangan pada penelitian ini menjelaskan bahwa proses pembelajaran yang dilakukan saat ini cukup efektif meskipun disana-sini masih ada beberapa hambatan yang mengganggu pembelajaran jarak jauh seperti masalah interaksi sosial guru dengan siswa dan ekonomi peserta didik yang nyaris belum siap.

\section{Saran}

Berdasarkan hasil penelitian yang telah dipaparkan, dapat diberikan saran yang semoga dapat membangun, diantaranya:

1. Sebelum dilaksanakannya program pembelajaran jarak jauh perlu dipersiapkan fasilitas pendukung, kompetensi serta pelatihan terlebih dahulu kepada siswa, guru dan orang tua. 
2. Selama proses pembelajaran jarak jauh orang tua turut serta mendampingi siswa, untuk mempersiapkan kegiatan pembelajaran sehingga siswa dapat mengikuti pembelajaran jarak jauh.

3. Seharusnya pemerintah dan manajemen sekolah mengupayakan, memudahkan, dan mengoptimalkan segala fasilitas dan kebutuhan pembelajaran jarak jauh baik bagi guru maupun bagi siswa agar kualitas pembelajaran yang dilaksanakan masih terjaga kualitasnya.

\section{REFERENCES}

Al-Tabany, T. I. B. (2017). Mendesain Model Pembelajaran Inovatif, Progresif, dan Kontekstual. Jakarta: KENCANA.

Dewi, W. A. F. (2020). Dampak Covid 19 Terhadap Implementasi Pembelajaran Daring di Sekolah Dasar. Edukatif. Jurnal Pendidikan. Vol 2 No 1 (2020). https:// edukatif.org/ index.php/ edukatif /article/view/89 DOI: https: //doi.org/10.31004/ edukatif.v2i1.89

Firdaus, A. M. (2016). Efektivitas pembelajaran matematika melalui penerapan model pembelajaran kooperatif tipe snowball throwing. BETA: Jurnal Tadris Matematika. Vol 9 No 1 (2016). https: //jurnalbeta.ac.id /index.php/betaJTM/article/view/1 DOI 10.20414/Betajtm.V9i1.1

Firman, \& Rahman, S. R. (2020). Pembelajaran Online di Tengah Pandemi Covid-19. IJES: Indonesian Journal Of Education Science. Vol 2 No 2 (2020). https: //ojs.unsulbar.ac.id/ index.php/ijes /article/view/659 DOI: https: //doi.org/ 10.31605 /ijes.v2i2.659

Munir. (2012). Pembelajaran Jarak Jauh Berbasis Teknologi Informasi dan Komunikasi. Bandung: Alfabeta.

Rahmawati, I. (2020). Pelatihan Dan Pengembangan Pendidikan Jarak Jauh berbasis Digital Class Platform Edmodo.

Rohmawati, A. (2015). Efektivitas Pembelajaran. : Jurnal Pendidikan Usia Dini Vol 9 No 1 (2015). http: // journal.unj.ac.id / unj/index.php / jpud / article /view/3491

Sugiyono. (2013). Memahami Penelitian Kualitatif. Bandung: Alfabeta. . (2017). Metode Penelitian Kuantitatif, Kualitatifdan R\&D. Bandung: Alfabeta.

Tandra, H. (2020). Virus Corona Baru Covid-19 Kenali, Cegah, Lindungi Diri Sendiri \& Orang Lain. Yogyakarta: Rapha Publishing.

Usman, M. H., \& Aswar. (2020). Covid-19 Dalam Perjalanan Akhir Zaman: Sebab, Dampak Dan Anjuran Syariat Dalam Menghadapinya. Bustanul Fugqoha: Jurnal Bidang Hukum Islam. Vol 1 No 2 (2020). https://journal.stiba.ac.id/index. php/bustanul /article/view/142. DOI: https ://doi.org/10.36701/ bustanul.v1i2.142

Purwanto, A., Rudy Pramono, Masduki Asbari, Priyono Budi Santoso, Laksmi Mayesti Wijayanti, Choi Chi Hyun, Ratna Setyowati Putri. (2020) Studi Eksploratif Dampak Pandemi COVID-19 Terhadap Proses Pembelajaran Online di Sekolah Dasar. Journal of Education, Psychology and counseling. Vol 2 No 1 (2020). https://ummaspul.e-journal.id/Edupsycouns/article/view/397

Yerusalem, M. R., \& dkk. (2020). Desain dan Implementasi Sistem Pembelajaran Jarak Jauh Di Program Studi Sistem Komputer. Jurnal Teknologi dan Sistem Komputer. Vol 3 No. 4 (2015). https: //jtsiskom.undip.ac.id/index. php/ jtsiskom /article/view/ 12668 DOI: https ://doi.org/10.14710/ jtsiskom.3.4.2015.481-492

Zulva, T. N. I. (2020). Covid-19 Dan Kecenderungan Psikosomatis. academia.edu. UIN Wali Songo Semarang. 